\title{
RANCANG BANGUN SISTEM INFORMASI PENYALUR DANA BANTUAN SISWA ( BOS ) BERBASIS WEB
}

\author{
Harfizar $^{1}$, Fauzan Manafi Albar ${ }^{2}$, Muh afiffudin ${ }^{3}$ \\ Dosen STMIK Raharja ${ }^{1,2}$, Mahasiswa Perguruan Tinggi Raharja ${ }^{3}$. \\ Jl. Jendral Sudirman No. 40, Modernland, Tangerang ${ }^{1,2,3}$ \\ e-mail : harfizar@ raharja.info ${ }^{1}$, fauzan@ raharja.info $^{2}$, afiffudin@ raharja.info ${ }^{3}$
}

\begin{abstract}
Abstrak
Penerapan Teknologi Informasi saat ini telah menyebar hampir di semua bidang tidak terkecuali dalam pengelolaan Dana Operasional Sekolah memungkinkan seluruh kegiatan pengelolaan dana bantuan operasional memanfaatkan teknologi informasi.Kebutuhan akan Teknologi Informasi sangat berhubungan dengan peran dari pengelolaan dana bos sebagai program standar pendidikan yang diperlukan untuk membiayai kegiatan operasi nonpersonalia selama 1 (satu) tahun sebagai bagian dari keseluruhan dana pendidikan agar satuan pendidikan dapat melakukan kegiatan pendidikan secara teratur dan berkelanjutan sesuai dengan Standar Nasional Pendidikan. Dengan dibangunnya Aplikasi Sistem Informasi Manajemen "ASISMEN" Bantuan Operasional Sekolah "BOS", yakni dapat memberikan informasi kepada orang kepala sekolah maupun bendahara sekolah atau lembaga pendidikan mengenai masalah penyaluran keuangan dana BOS tersebut. Agar informasi yang diberikan disajikan dalam bentuk laporan khusus sehingga dapat disajikan secara tepat dan periodik mudah dimengerti dan mudah dalam penggunaannya. Salah satu contohnya adalah penerapan sistem informasi keuangan di perusahaan-perusahaan atau lembaga-lembaga lain, begitu juga di SDN Tamgerang Hasil akhir dari penelitian ini berupa sistem yang dapat menyajikan laporan yang akurat dan uptodate sehingga memenuhi tujuan yang ingin dicapai dalam standar 8 pendidikan nasional yang di tetapkan oleh pemerintah pusat.
\end{abstract}

Kata Kunci : Asismen, BOS, Pendidikan

\begin{abstract}
Application of Information Technology has now spread almost in all fields is no exception in the management of the School Operational Fund allows all operational funds management activities informasi.Kebutuhan technology will utilize information technology is closely connected with the role of fund management boss as a standard program of education that is needed to finance the activities nonpersonnel operation for 1 ( one ) year as part of the overall education funding to education units can conduct educational activities on a regular and ongoing basis in accordance with National Education Standards . With the construction of Management Information Systems Applications " ASISMEN "School Operational Assistance "BOS", which can provide information to the school principal and school treasurer or educational institutions regarding the distribution of financial problems by the BOS. So that the information provided is presented in the form of special reports that can be presented properly and periodically easily understood and easy to use. One example is the implementation of financial information systems in enterprises or other institutions, as well as in SDN Tangerang The final result of this research is a system that can provide accurate and up to date report that meets the objectives of the national education standard 8 set by the central government.
\end{abstract}

Keywords :Asismen,BOS,Educatn

\section{PENDAHULUAN}

Penerapan Teknologi Informasi saat ini telah menyebar hampir di semua bidang tidak terkecuali dalam pengelolaan Dana Operasional Sekolah. Atas dasar Undang-Undang Nomor 20 Tahun 2003 tentang Sistem Pendidikan Nasional mengamanatkan bahwa setiap warga negara yang berusia 7-15 tahun wajib mengikuti pendidikan dasar. Pasal 34 ayat 2 menyebutkan bahwa Pemerintah 
pusat dan pemerintah daerah menjamin terselenggaranya wajib belajar minimal pada jenjang pendidikan dasar tanpa memungut biaya, sedangkan dalam ayat 3 menyebutkan bahwa wajib belajar merupakan tanggung jawab negara yang diselenggarakan oleh lembaga pendidikan Pemerintah, pemerintah daerah, dan masyarakat. Pada perkembangan dewasa ini memungkinkan seluruh kegiatan pengelolaan dana bantuan operasional memanfaatkan teknologi informasi. Kebutuhan akan Teknologi Informasi sangat berhubungan dengan peran dari pengelolaan dana bos sebagai program standar pendidikan yang diperlukan untuk membiayai kegiatan operasi nonpersonalia selama 1 (satu) tahun sebagai bagian dari keseluruhan dana pendidikan agar satuan pendidikan dapat melakukan kegiatan pendidikan secara teratur dan berkelanjutan sesuai dengan Standar Nasional Pendidikan.

Dari uraian diatas memberikan gambaran bahwa sistem yang ada sekarang ini masih banyak kesulitan mengontrol anggaran operasional setiap Triwulannya, sehingga masih banyak terdapat anggaran dana bantuan operasional sekolah yang melibihi dari anggaran yang di tetapkan sebelumnya di Rencana Kegiatan Anggaran Sekolah (RKAS). Ini akan berdampak terhadap Program Pemerintah dengan tidak terpenuhinya Program 8 Standar Pendidikan Nasional yang terdiri dari Pengembangan Standar isi Pengelolaan Kurikulum, Pengembangan Standar Proses, Pengembangan Standar Kelulusan, Pengembangan Standar Pendidik dan Tenaga Kependidikan, Pengembangan Standar Sarana dan Prasarana, Pengembangan Standar Pengelolaan, Pengembangan Standar Pembiayaan, dan Pengembangan Standar Penilaian. Sehingga sudah seharusnyalah badan lembaga pendidikan khususnya SDN Kota Tangerang dapat menjalankan 8 Program Standar Pendidikan Nasional yang mana telah di tetapkan dengan Peraturan Mendiknas nomor 69 Tahun 2009 yang berbunyi standar biaya operasi nonpersonalia adalah standar biaya yang diperlukan untuk membiayai kegiatan operasi nonpersonalia selama 1 (satu) tahun sebagai bagian dari keseluruhan dana pendidikan agar satuan pendidikan dapat melakukan kegiatan pendidikan secara teratur dan berkelanjutan sesuai Standar Nasional Pendidikan.

\subsection{Permasalahan}

Sesuai dengan uraian latar belakang masalah, maka permasalahan yang akan dibahas yaitu "Perancangan Sistem Informasi Penyaluran dana Bantuan Operasional Sekolah (BOS) Berbasis WEB Pada SD Negeri kota Tangerang".

Penelitian ini adalah untuk meningkatkan penggunaan anggaran Bantuan Operasional Sekolah agar tepat pada Komponen Program 8 Standar Pendidikan Nasional yang terdapat didalam Buku Petunjuk Teknis (Juknis) BOS sesuai tahun anggaran yang berlaku. Manfaat yang ingin dicapai melalui penelitian ini agar nantinya sistem yang dibangun bisa digunakan untuk mengefisiensikan dan mempermudah pekerjaan dalam pengelolaan dana anggaran bantuan operasional sekolah.

Adapun perumusan masalah pada penyaluran dana bantuan (BOS) adalah sebagai berikut :

1. Bagimana sistem pengelolahan anggaran dana BOS yang berjalan pada saat ini ?

2. Faktor-faktor apakah yang berperan dalam membangun sistem informasi pengelolaan anggaran BOS supaya dapat terkontrol dalam penggunaannya ?

3. Bagaimana teknik mengurangi tingkat kesalahan pelaporan dana Bantuan Operasional Sekolah yang relatif tinggi.

4. Bagaimana merancang Sistem Informasi Pengelolaan Dana Bantuan Operasional Sekolah Berbasis web dan mengimplementasikannya?

\section{LANDASAN TEORI}

\subsection{Definisi Sistem}

Berikut ini adalah beberapa definisi sistem menurut beberapa ahli, diantaranya:

Menurut Abdul Kadir (2014:61), "Sistem adalah sekumpulan elemen yang saling terkait atau terkait atau terpadu yang dimaksudkan untuk mencapai suatu tujuan".

Menurut Ross.D.Arnold \& Jon.P.Wade dalam "International Conference on Enterprise Information System - Procedia Computer Science (2015:675), "Systems : Groups or combinations of interrelated, interdependent, or interacting elements forming collective entities". 
Menurut Suprihadi dalam Jurnal CCIT (2013:310), "Sistem adalah sekumpulan unsur atau elemen yang saling berkaitan dan saling mempengaruhi dalam melakukan kegiatan bersama untuk mencapai suatu tujuan".

Berdasarkan beberapa pendapat yang terdapat diatas, maka dapat disimpulkan bahwa "Sistem adalah sekelompok elemen yang saling terhubung dan berinteraksi satu sama lain untuk mencapai suatu tujuan tertentu yang telah ditetapkan".

\subsection{Karakter Sistem}

Ada sepuluh karakteristik sistem yang dikemukakan oleh: Bambang Hartono, (2013:9)

1. Komponen Sistem (Componen System)

Bagian-bagian atau elemen-elemen, yang dapat berupa benda atau manusia, berbentuk nyata atau abstrak, dan disebut subsistem.

2. Penghubung antarbagian (Interface)

Suatu yang bertugas menjembatani satu bagian dengan bagian lain, dan memungkinkan terjadinya interaksi/komunikasi antarbagian.

3. Batas (Boundary)

Sesuatu yang membedakan antara satu sistem dengan sistem atau sistem-sistem lain.

4. Lingkungan (Enviroment)

Segala sesuatu yang berada diluar sistem dan dapat bersifat menguntungkan atau merugikan sistem yang bersangkutan.

5. Masukan (Input)

Sesuatu yang merupakan bahan diolah atau diproses oleh sistem.

6. Mekanisme Pengolahan (Processimg)

Perangkat dan prosedur untuk mengubah masukan menjadi keluaran dan menampilkannya.

7. Keluaran (Output)

Berbagai macam bentuk hasil atau produk yang dikeluarkan dari pengolahan.

8. Tujuan (Goal/objective)

Sesuatu atau keadaan yang ingin dicapai oleh sistem, baik dalam jangka pendek maupun jangka panjang.

9. Sensor dan Kendali (Sensor \& Control)

sesuatu yang bertugas memantau dan mengifornasikan perubahan-peruabahan di dalam lingkungan dan dalam diri sistem kepada sistem.

10.Umpan Balik (Feedback)

Informasi tentang perubahan-perubahan lingkungan dan perubahan-perubaha (penyimpanan) dalam diri sistem mengembalikannya ke kondisi normal.

\subsection{Klasifikasi Sistem}

2013:8)

Sistem dapat diklasifikasikan dari beberapa sudut pandang diantaranya: ( Rohmat Taufiq,

1. Sistem Abstrak (Abstract System) dan Sistem Fisik (Physical System).

Sistem abstrak merupakan sistem yang berupa pemikiran atau ide-ide yang tidak tampak secara fisik. Misalnya sistem teologi, yaitu sistem yang berupa pemikiran-pemikiran hubungan anatara manusia dengan Tuhan. Sistem fisik merupakan sistem yang ada secara fisik. Misalnya sistem komputer, sistem produksi, dan sistem transportasi.

2. Sistem Dapat Dipastikan dan Sistem Tidak Dapat Dipastikan.

Sitem dapat dipastikan merupakan suatu sistem yang input proses dan output sudah ditentukan sejak awal. Sudah dideskripsikan dengan jelas apa inputnya seperti apa. Sedangkan sistem tidak dapat dipastikan atau sistem probabilistik merupakan sebuah sistem yang belum terdefinisi dengan jelas salah satu dari input-proses-output atau ketiganya belum terdefinisi dengan jelas.

3. Sistem Tertutup dan Sistem Terbuka.

Sistem terututp dan sistem terbuka yang membendakan adalah ada faktor-faktor yang mempengaruhi dari luar sistem atau tidak, jika tidak ada faktor-faktor yang mempengaruhi dari luar iti bisa disebut dengan sistem tertutup tapi jika ada pengaruh komponen dari luar disebut sistem terbuka. 


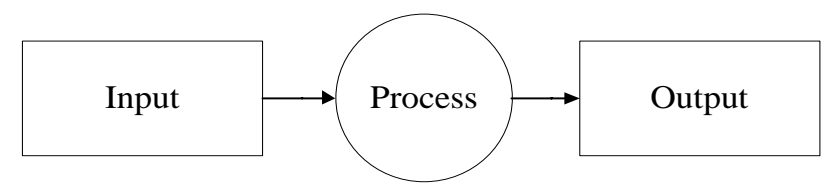

Sumber : Taufiq (2013:9)

Gambar 2.1 Sistem tertutup

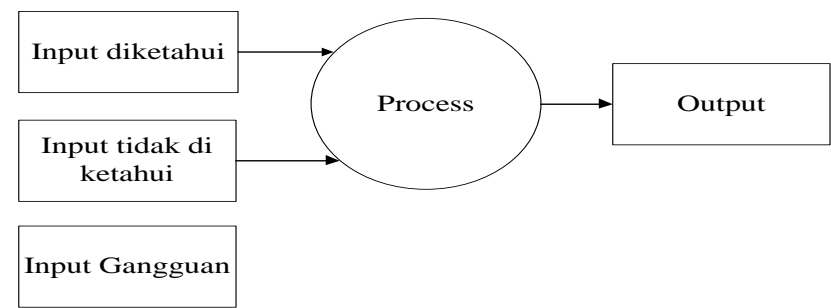

Sumber : Taufiq (2013:9)

Gambar 2.2.Sistem Tertutup

4. Sistem Manusia dan Sistem Mesin

Sistem manusia dan sistem mesin merupakan sebuah klasifikasi sistem jika dipandang dari pelakunya. Pada zaman yang semakin global dan semuanya serba maju ini tidak semua sistem dikerjakan oleh manusia tapi beberapa sistem dikerjakan oleh mesin tergantung dari kebutuhannya. Sistem manusia adalah suatu sistem yang proses kerjanya dilakukan oleh manusia sebagai contoh pelaku sistem organisasi, sistem akademik yang masih manual, transaksi jual beli dipasar tradisional,dll. Adapun sistem mesin merupakan sebuah sistem yang proses kerjanya dilakukan oleh mesin, sebagai contoh sistem motor, mobilm mesin industri, dan lain-lain,

5. Sistem Sederhana dan Sistem Kompleks

Sistem dilihat dari tingkat kekomplekan masalahnya dibagi menjadi dua yaitu sistem sederhana dan sistem kompleks. Sistem sederhana merupakan sistem yang sedikit subsistemnya dan komponen-komponennya pun sedikit. Adapun sistem kompleks adalah sistem yang banyak subsub sistemnya sehingga proses dari sistem itu sangat rumit.

6. Sistem bisa beradaptasi dan sistem tidak bisa beradaptasi

Sistem yang bisa beradaptasi terhadap lingkungannya merupakan sebuah sistem yang mampu bertahan dengan adanya perubahan lingkungan. Sedangkan sistem yang tidak bisa beradaptasi dengan lingkungan merupakan sebuah sistem yang tidak mampu bertahan jika terjadi perubahan lingkungan.

7. Sistem Alamiah (Natural System) dan Sistem Buatan Manusia (Human Made System)

Sistem alamiah adalah sisten yang terjadi melalui proses alam, tidak dibuat manusia. Misalnya sistem tata surya. Sistem buatan manusia adalah sistem yang melibatkan interaksi manusia dengan mesin yang disebut human machine system. Misalnya sistem telekomunikasi.

8. Sistem Sementara dan Sistem Selamanya.Sistem sementara dan sistem selamanya merupakan klasifikasi sistem jika dilihat dari pemakainya. Sistem sementara merupakan sebuah sistem yang dibangun dan digunakan untuk waktu sementara, sebagai contoh sistem pemilihan presiden, setelah proses pemillihan presiden sudah tidak dipakai lagi dan untuk pemilihan lima tahun mendatang kemungkinan sistem selamanya merupakan sistem yang dipakai untuk jangka panjang atau digunakan selamanya, misalnya sistem pencernaan.

\subsection{Definisi Informasi}

Berikut ini adalah pengertian Definisi Informasi dari beberapa ahli, yaitu:

Menurut Tohari Hamim (2014:7), "Informasi adalah data yang telah diproses sedemikian rupa sehingga memiliki arti yang lebih bermanfaat bagi penggunanya" 
Menurut Bambang Hartono (2013:15), "Informasi pada dasarnya adalah sehimpunan data yang telah diolah menjadi sesuatu yang memiliki arti dan kegunaan lebih luas".

Maimunah, Lusyani Sunarya, dkk dalam jurnal CCIT (2012:57)," Informasi adalah data yang telah diolah menjadi sebuah bentuk yang lebih berarti bagi penerimanya dan bermanfaat dalam mengambil suatu keputusan".

Berdasarkan beberapa pendapat yang dikemukakan di atas dapat di tarik kesimpulan bahwa "Informasi adalah fakta yang telah diolah dengan cara tertentu yang menggambarkan suatu kejadian nyata untuk diolah agar dapat dipahami dan digunakan dalam pengambilan suatu keputusan".

\subsection{Struktur Informasi}

Struktur Informasi adalah hubungan antar data (antar-record), yang dapat berupa hubungan Hierarkis atau hubungan asosiatif: ( Bambang Hartono, 2013:86).

1. Hubungan Hierarkis adalah hubungan berjenjang yang bersifat "atasan-bawahan". Contoh: record tentang gaji atau record tentang hutang seorang karyawan merupakan "bawahan" dari record tentang karyawan tersebut.

2. Hubungan Asosiatif adalah hubungan antar data (antar-record) hal yang terjadi karena kesesama isi atau nilai dari data (records) tersebut. Misalnya kesamaan dalam hal tempat kerja.

\subsection{Definisi Sistem Informasi}

Berikut ini adalah pengertian Definisi Sistem Informasi dari beberapa ahli, yaitu :

I Putu Agus Eka Pratama (2014:10) menyatakan bahwa: Sistem Informasi merupakan bagian dari empat bagian utama. Keempat bagian utama tersebut mencakup perangkat lunak (software), perangkat keras (hardware), infrastruktur,dan Sumber Daya Manusia (SDM) yang terlatih. Keempat bagian utama ini saling berkaitan untuk menciptakan sebuah sistem yang dapat mengolah data menjadi informasi yang bermanfaat.

Menurut Taufiq Rohmat (2013:17), Sistem Informasi adalah kumpulan dari sub-sub sistem yang saling terintegrasi dan berkolaborasi untuk menyelesaikan masalah tertentu dengan cara mengolah data dengan alat yang namanya komputer sehingga memiliki nilai tambah dan bermanfaat bagi pengguna.

Berdasarkan beberapa pendapat diatas peneliti dapat menarik kesimpulan bahwa sistem informasi adalah komponen-komponen yang membentuk sistem yang menghasilkan suatu informasi yang berfungsi sebagai penyedia informasi atau laporan.

\subsection{Komponen-komponen Sistem Informasi}

Komponen-komponen yang terdapat didalam semua jenis sistem informasi mencakup tujuh poin. Berikut ketujuh komponen tersebut beserta dengan penjelasan masing-masing: ( I Putu Agus Eka Pratama, 2014:11)

1. Input (Masukan)

Sebuah informasi berasal dari data yang telah diolah dan diverifikasi sehingga akurat, bermanfaat, dan memiliki nilai. Komponen input ini berfungsi untuk menerima semua input (masukan) dari pengguna, inputan yang diterima dalam bentuk data. Data ini berasal dari satu maupun beberapa buah sumber.

2. Output (Keluaran)

Sebuah sistem informasi akan menghasilkan keluaran (Output) berupa informasi. Komponen output berfungsi untuk menyajikan hasil akhir ke pengguna sistem informasi.

3. Software (Perangkat Lunak)

Komponen software (perangkat lunak) mencakup semua perangkat lunak yang digunakan didalam sistem informasi. Adanya komponen perangkat lunak ini membatu sistem informasi didalam menjalankan tugasnya dan untuk dapat dijalankan sebagainya mestinya.

4. Hardware (Perangkat Keras)

Komponen hardware ( perangkat keras) mencakup semua perangkat komputer yang digunakan secara fisik didalam sistem informasi, baik dikomputer server maupun dikomputer client.

5. Database (Basis Data) 
Komponen basis data berfungsi untuk menyimpan semua data dan informasi kedalam satu atau beberapa tabel. Setiap tabel memiliki field masing-masing. Setiap tabel memiliki fungsi penyimpanan masing-masing, serta atar tabel dapat juga terjadi relasi (hubungan).

6. Kontrol dan Prosedur

Kontrol dan prosedur adalah dua buah komponen yang menjadi satu. Komponen kontrol berfungsi untuk mencegah terjadinya beragam gangguan dan ancaman terhadap data dan informasi yang ada didalam sistem informasi, termasuk juga sistem informasi itu sendiri beserta fisiknya (dalam hal ini komputer server).

7. Tekonologi dan Jaringan Komputer

Komponen terakhir didalam sistem informasi ini, yaitu teknologi jaringan komputer, memegang peranan terpenting untuk sebuah sistem informasi. Komponen teknologi mengatur software, hardware, database, kontrol dan prosedur, input dan output.

\subsection{Literature Review}

Banyak penelitian yang sebelumnya (literature review)dilakukan mengenai pembahasan tentang perancangan sistem informasi penyaluran dana bantuan operasional sekolah (BOS) berbasis web pada dunia pendidikan saat ini. Dalam melakukan perancangan dana BOS ini perlu dilakukan studi pustaka untuk dijadikan sebagai bahan acuan untuk memperkuat hasil penelitian dengan cara mengindetifikasikan metode yang pernah dilakukan, perancangan penelitian sebelumnya yang memiliki korelasi yang seimbang dengan sistem penyaluran dana BOS Pada SDN Kota Tangerang. Beberapa literature review yang didapatkan diantaranya adalah sebagai berikut :

1. Penelitian yang dilakukan oleh Rio Ridha Ariestyo (2013). Mahasiswa Jurusan Teknologi InformatikaPoliteknik Elektronika Negeri SurabayaInstitut Teknologi Sepuluh Nopember. Penelitian yang dilakukan dengan judul "Sistem Informasi Pengelolaan Dana Bantua Operasional Sekolah ( Bos ) Di Smp Surabaya".Sistem pelaporan dana Batuan Operasional Sekolah (BOS) saat ini masih menggunakan systemmanual, hal tersebut sering timbul kesalahan yang merepotkan pengelolah BOS harus selalu revisi laporankepada dinas pendidikan. Pengertian dana BOS sendiri adalah program pemerintah untuk penyediaanpendanaan biaya nonpersonalia bagi satuan pendidikan dasar dan menengah sebagai sarana pelaksanaanprogram wajib belajar 9 tahun. Program BOS bertujuan untukmembebaskan segala jenis biaya pendidikanbagi seluruh siswa SD, SMP negeri dan swasta di Indonesia dari biaya operasional sekolah.

Pada proyek akhir ini akan dirancang system informasi pengelolaan dana BOS di SMP Surabaya,dalam bentuk aplikasi web yang menggunakan bahasa pemrograman PHP dan database My SQL. Sisteminformasi ini dapat membantu sekolah dalam proses penyusunan rencana anggaran pendapatan belanjasekolah (RAPBS) setiap tahun, dan penyusunan realisasi pelaporan penggunaan dana BOS setiaptriwulannya dalam bentuk buku kas umun (BKU) sehingga memudahkan dinas pendidikan dalampengecakan pelaporan dana bantuan operasional sekolah yang telah disalurkan ke sekolah.

2. Penelitian yang dilakukan oleh Sharipuddin Jurusan Sistem Informasi STIKOM Dinamika Bangsa, Jambi. Pelaporan penggunaan yang berjudul "analisis dan perancangan sistem informasi Penerima bantuan pada federasi serikat buruh demokrasi seluruh indonesia (fsbdsi) periode berbasis web".Federasi Serikat Buruh Demokrasi Seluruh Indonesia (FSBDSI) merupakan salah satu instansi di Indonesia yang belum memanfaatkan penggunaan sistem dan teknologi informasi secara optimal. Terlihat dari belum adanya sistem informasi yang terintegrasi antara satu dengan yang lainnya, sehingga masih terdapat beberapa kendala dalam pengolahan data penerima dana bantuannya, diantaranya adalah terjadi inkonsistensi dan redudansi data, kurangnya keakuratan data, lamanya proses pencarian data, serta sulitnya menyebarkan informasi mengenai FSBDSI kepada para anggota. Untuk mengatasi masalah tersebut diperlukan sebuah sistem informasi penerima bantuan berbasis web. Sistem informasi penerima bantuan ini dirancang dengan menggunakan bahasa pemograman PHP dan metodologi yang digunakan dalam analisis dan perancangan sistem informasi ini ialah model analisa dan desain UML (Unified Modelling Language) yang digambarkan dalam bentuk diagram Use Case, Diagram Class, dan Diagram Activity. Output dari penelitian ini adalah rancangan prototype sistem informasi penerima bantuan pada FSBDSI berbasis web Periode II Kabupaten 
Tebo. Dengan adanya sistem informasi penerima bantuan ini diharapkan dapat memberikan wadah berupa web yang dapat melakukan pengolahan data dengan baik dan terintegrasi, serta dapat membantu penyebaran informasi kepada semua pihak yang berkepentingan.

3. Penelitian sejenis juga dilakukan oleh Suryati dan Bambang Eka Purnama (2012) dengan judul "Pembangunan Sistem Informasi Pendataan Rakyat Miskin Untuk Program Beras Miskin (Raskin) pada Desa Mantren Kecamatan Kebonagung Kabupaten Pacitan”.

Penelitian tersebut bertujuan untuk menghasilkan sistem informasi pendataan rakyat miskin untuk program beras miskin (Raskin) pada Desa Mantren Kecamatan Kebonagung Kabupaten Pacitan. Penelitian tersebut memiliki manfaat dalam meminimalisasi kesalahan dalam penginputan data dan juga dapat mempermudah kinerja pegawai dalam mengolah data rakyat miskin.

Dari penelitian yang dilakukan oleh Suryati dan Bambang Eka Purnama tersebut dapat disimpulkan bahwa penelitiannya menghasilkan sebuah aplikasi desktop yang dapat digunakan dalam pengolahan data rakyat miskin untuk program beras miskin pada Desa Mantren Kecamatan Kebonagung Kabupaten Pacitan.

\section{HASIL DAN PEMBAHASAN}

\subsection{Usulan Rancangan Sistem}

Berdasarkan hasil penelitian dan analisa yang dilakukan terhadap sistem yang berjalan pada SD Negeri kota Tangerang, menunjukkan bahwa terdapat beberapa masalah atau kendala yang terjadi, oleh karena itu penulis mengajukan usulan sistem baru yang diharapkan dapat mengatasi masalahmasalah yang terjadi khusunya dalam hal sirkulasi pencatatan dan laporan operasional penggunaan dana BOS. Adapun prosedur yang diusulkan yaitu perancangan Aplikasi Sistem Informasi Manajemen Sekolah pada SD Negeri Kota Tangerang.

Dalam tahap ini akan diuraikan UML (Unified Modelling Language) yang diusulkan, rancangan basis data, rancangan tampilan, dan implementasi sistem yang diusulkan.

Selanjutnya akan dibahas mengenai rancangan usulan sistem yang akan dibangun. Ada beberapa usulan prosedur baru, prosedur yang bertujuan memperbaiki dan menyempurnakan sistem yang ada sekarang.

\subsection{Diagram Rancangan Sistem}

Untuk menganalisa sistem yang diusulkan, pada penelitian ini digunakan program visual Paradigm for UML 6.4. untuk menggambarkan Use Case Diagram, Sequence Diagram, Activity Diagram, Statechart Diagram, dan Class Daigram.

\section{Use Case Diagram Yang Diusulkan}

Use case diagram menggambarkan fungsionalitas yang diharapkan dari sebuah sistem. Yang ditekankan adalah "apa" yang diperbuat sistem, dan bukan "bagaimana". Sebuah use case merepresentasikan sebuah interaksi antara aktor dengan sistem. Berikut adalah use case diagram yang diusulkan dalam perancangan system informasi penyaluran dana bantuan operasional sekolah. 


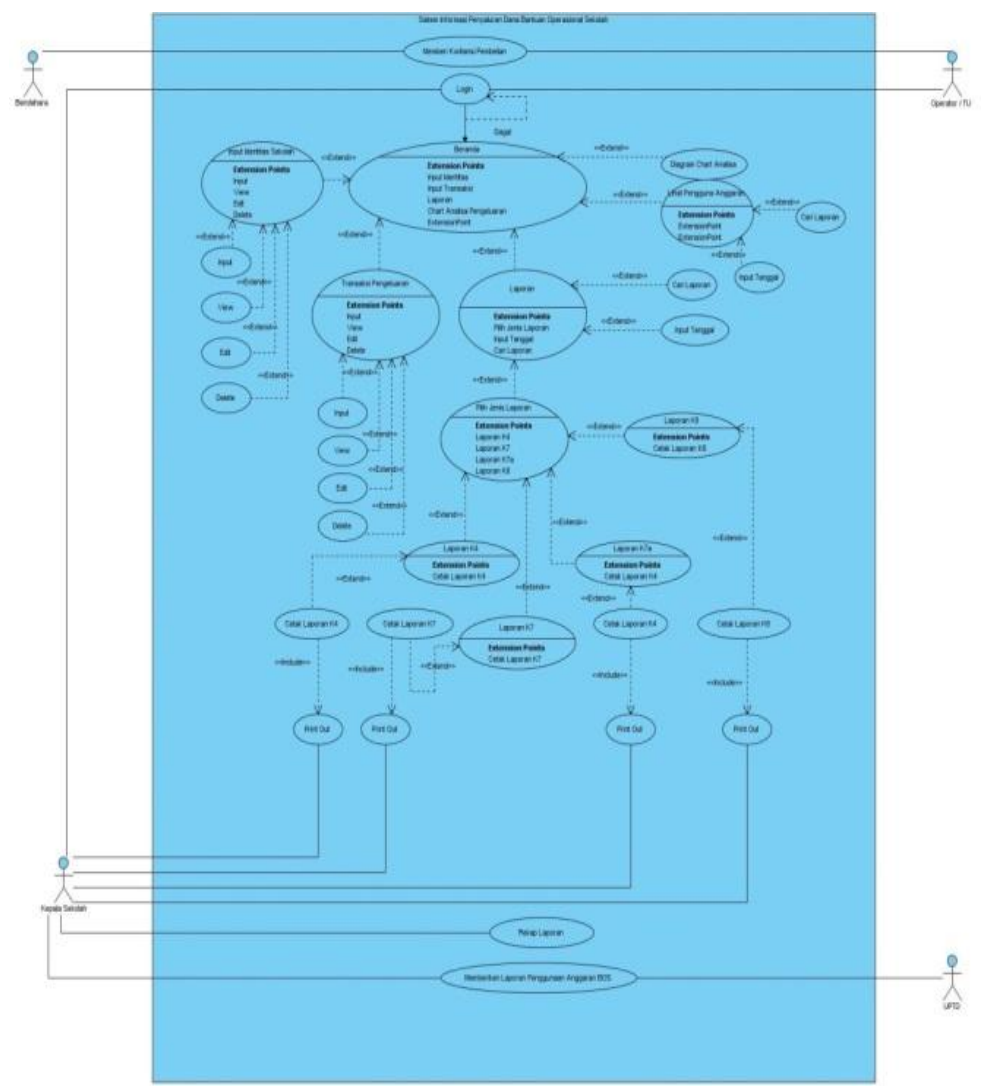

Gambar 1 Use Case Diagram sistem informasi penyaluran dana bos

Berdasarkan gambar 1 Use Case Diagram yang diusulkan terdapat :

a. 1 (satu) sistem yang mencakup seluruh kegiatan sistem informasi penyaluran dana bantuan operasional sekolah.

b. 4 (empat) actor yang digeneralization dalam sistem informasi penyaluran dana bantuan operasional sekolah yaitu terdiri dari bendahara, operator / Tata usaha, Kepala Sekolah, UPTD. 35 (tiga puluh lima) Use Case yang biasa dilakuakan oleh actor tersebut. 


\section{Sequence Diagram Yang Diusulkan}

Sequence diagram merupakan sebuah diagram yang menggambarkan interaksi antar objek di dalam sebuah system. Sequence diagram terdiri dari dimensi horizontal (objek-objek) dan dimensi vertical (waktu). Diagram ini juga menggambarkan urutan event yang terjadi. Dan lebih detail dalam menggambarkan aliran data, termasuk data atau behavior yang dikirimkan atau diterima.

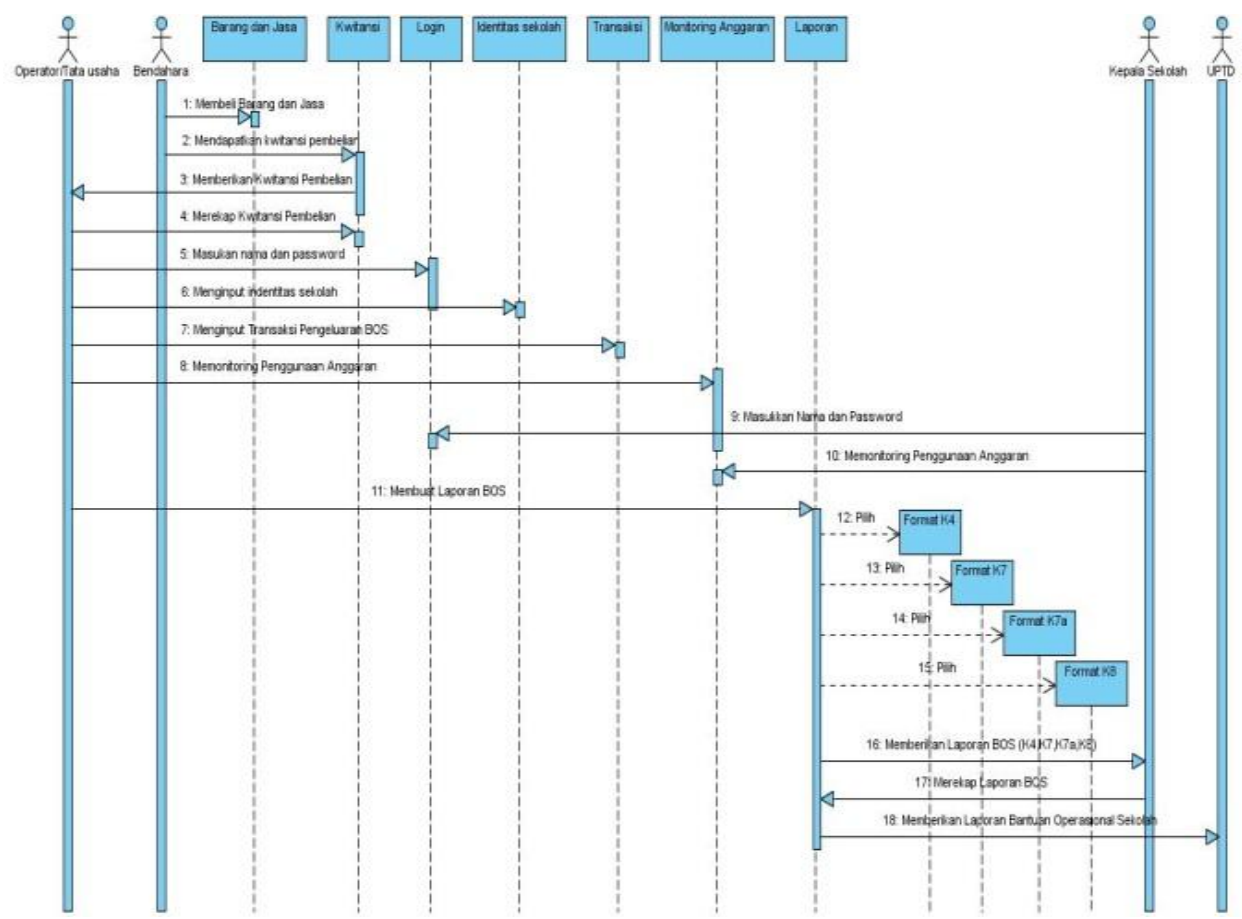

Gambar 2 Sequence Diagram sistem informasi penyaluran dana bos

Berdasarkan Gambar 2Squence Diagramyang diusulkan terdapat :

a. 1 Initial Node, objek yang diawali

b. $\quad 28$ Action State, dari sistem yang mecerminkan eksekusi aksi

c. 4 Fork Node

d. 1 final state, objek yang diakhiri

\section{Class Diagram Yang Diusulkan}

Class adalah sebuah spesifikasi yang jika diinstalisasi akan menghasilkan sebuah objek dan merupakan inti dari pengembangan dan desain berorientasi objek. Class menggambarkan keadaan suatu objek, sekaligus menawarkan layanan untuk memanipulasi keadaan tersebut
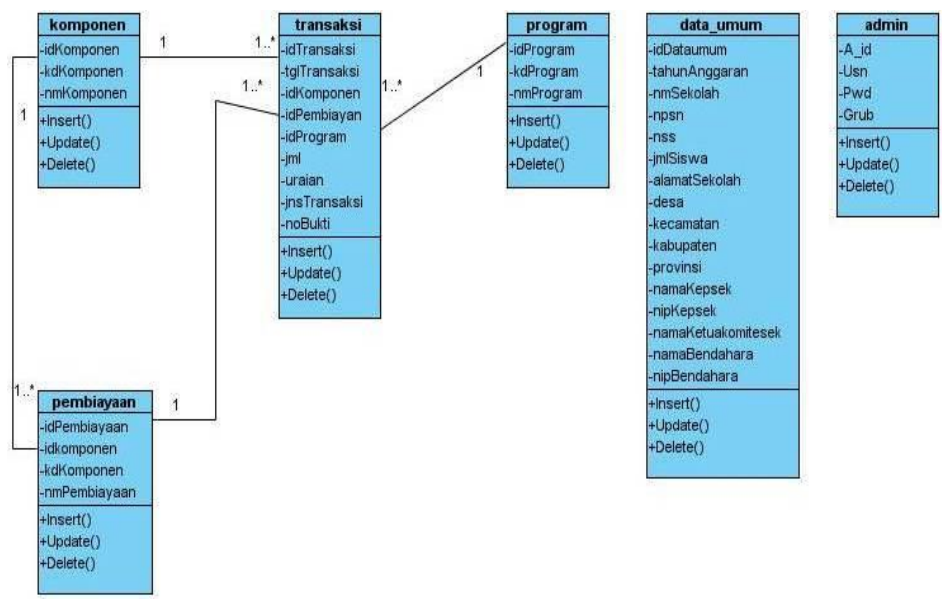

Gambar 3 Class Diagram sistem informasi penyaluran dana bos 
Pada Class Diagram informasi penyaluran dana bantuan operasional sekolah SDN Kota Tangerang terdapat 5 (lima) class, meliputi:

1. Class data_umum

2. Class transaksi

3. Class program

4. Class pembiayaan

5. Class komponen

Perbedaan Prosedur Antara Sistem Berjalan dan Sistem Usulan

\begin{tabular}{|c|l|l|}
\hline \multicolumn{3}{|c|}{ Tabel 1 Perbedaan Sistem Berjalan dengan usulan } \\
\hline No & \multicolumn{1}{|c|}{ Sistem Berjalan } & \multicolumn{1}{c|}{ Sistem Usulan } \\
\hline 1 & $\begin{array}{l}\text { Sistem yang berjalan saat ini } \\
\text { masih terlalu melakukan } \\
\text { banyak proses }\end{array}$ & $\begin{array}{l}\text { Membangung sistem menejemen yang baik dengan } \\
\text { terkomputerisasi, }\end{array}$ \\
\hline 2. & $\begin{array}{l}\text { Mengevaluasi anggara dana } \\
\text { Bantuan Operasional Sekolah } \\
\text { masih terlalu rumit }\end{array}$ & $\begin{array}{l}\text { Monitoring transaksi penggunaan dana bos dengan } \\
\text { menggunkan dashboard. }\end{array}$ \\
\hline 3. & $\begin{array}{l}\text { Masih terdapat tidak } \\
\text { kesesuaian pembelanjaan } \\
\text { anggaran dengan juknis yang } \\
\text { telah ditetapkan oleh } \\
\text { pemerintah. }\end{array}$ & $\begin{array}{l}\text { Memiliki sistem yang terintegrasi dengan program } \\
\text { pemerintah dan dapat di monitoring oleh Kepala } \\
\text { Sekolah }\end{array}$ \\
\hline 4. & $\begin{array}{l}\text { Dalam pembuatan laporan } \\
\text { memakan waktu yang lama, } \\
\text { proses pembuatan tidak efisien }\end{array}$ & $\begin{array}{l}\text { Membuat sistem laporan yang baik, dan tidak } \\
\text { memakan waktu lama serta proses tidak berulang- } \\
\text { ulang }\end{array}$ \\
\hline
\end{tabular}

\subsection{Rancangan Basis Data}

Rancangan basis data berfungsi untuk menjelaskan secara terperinci rancangan-rancangan yang diusulkan pada bagian basis data yang merupakan penjabaran diagram-diagram diatas.

Spesifikasi databasemerupakan desain basis data yang dianggap telah normal. Desain database menjelaskan media penyimpanan yang digunakan, isi yang disimpan, primary key, dan panjang record. Spesifikasi database yang digunakan dalam sistem yang akan dibangun adalah sebagai berikut

1. Tabel User

Nama tabel : admin

Media : :hardisk

Isi : : $\quad$ username,password

Primary key : admin

Panjang record $\quad: 42$

Tabel 2 Spesifikasi basis data user

\begin{tabular}{|c|c|c|c|}
\hline Field & Type & Field Size & Keterangan \\
\hline Username & Varchar & 10 & Nama user \\
\hline Password & Varchar & 32 & Kata sandi \\
\hline
\end{tabular}

2. Tabel Data umum

Nama tabel : data_umum 


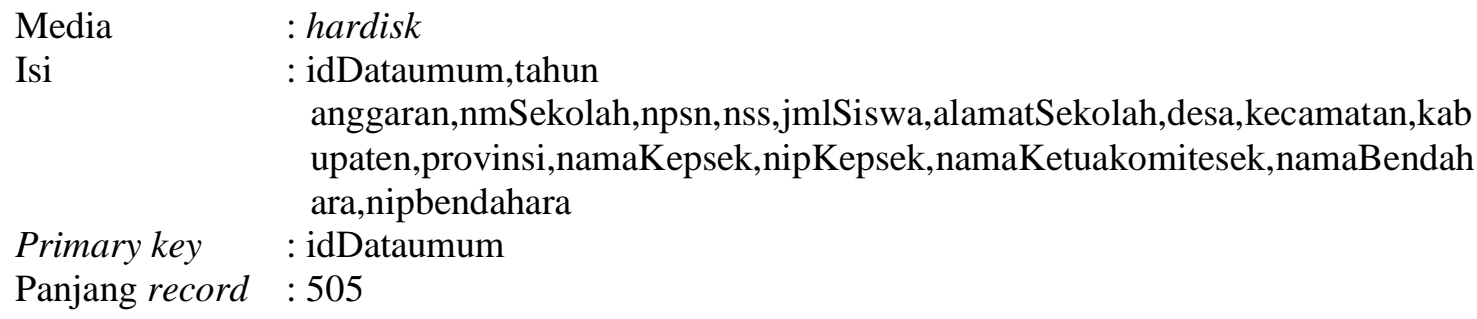

Tabel 3 Spesifikasi basis data umum

\begin{tabular}{|l|l|l|l|}
\hline Field & Type & Field size & keterangan \\
\hline iddataumum & Integer & 11 & Identitas Sekolah \\
\hline Tahunanggaran & integer & 4 & Tahun Anggaran \\
\hline nmSekolah & Varchar & 25 & Nama Sekolah \\
\hline Npsn & Tinyint & 25 & Nomor Pokok \\
\hline Nss & Interger & 25 & Nomor Statistic \\
\hline jmlSiswa & Interger & 10 & Jumlah Sekolah \\
\hline alamatSekolah & Varchar & 100 & Alamat Sekolah \\
\hline Desa & Varchar & 50 & Desa Sekolah \\
\hline Kecamatan & Varchar & 50 & Kecamatan Sekolah \\
\hline Kabupaten & Varchar & 50 & Kabupaten Sekolah \\
\hline Provinsi & Varchar & 50 & Provinsi Sekolah \\
\hline namaKepsek & Varchar & 20 & Nama Kepsek \\
\hline nipKepsek & Interger & 25 & Nip kepalaSekolah \\
\hline namaKetuakomitesek & Varchar & 20 & Nama ketuakomite \\
\hline namaBendahara & Varchar & 20 & Nama bendahara \\
\hline nipBendahara & Varchar & 20 & Nip bendahara \\
\hline
\end{tabular}

3. Tabel Komponen
Nama tabel :Komponen
Media : :hardisk
Isi :idKomponen,
KdKomponen,
Primary key
Panjang record : 478

Tabel 4 Spesifikasi basis data Komponen

\begin{tabular}{|l|l|l|l|}
\hline Field & Type & Field size & Keterangan \\
\hline idKomponen & Integer & 11 & Nomor induk karyawan \\
\hline KdKomponen & Varchar & 3 & Nama karyawan \\
\hline nmKomponen & Varchar & 100 & Nomor telepon karyawan \\
\hline
\end{tabular}

4. Tabel Pembiayaan
Nama tabel :pembiayaan
Media : :hardisk
Isi :idPembiayaan,
Primary key : idPembiayaan
idKomponen,kdKomponen,Kodepembiayaan,nmPembiayaan 
Panjang record : :111

Tabel 5 Spesifikasi basis data pembiayaan

\begin{tabular}{|l|l|l|l|}
\hline Field & Type & Field size & Keterangan \\
\hline IdPembiayaan & Integer & 11 & Id pembiayaan \\
\hline IdKomponen & Integer & 11 & Nama komponen \\
\hline KdKomponen & Varchar & 3 & Kode komponen \\
\hline Kodepembiayaan & Varchar & 5 & Kode Pembiayaan \\
\hline nmPembiayaan & Varchar & 200 & NamaPembiayaan \\
\hline
\end{tabular}

5. Tabel Program

Nama tabel :program

Media : :hardisk

Isi :idProgram,

kdProgram, nmProgram

Primary key : idProgram

Panjang record :72

Tabel 6 Spesifikasi basis data program

\begin{tabular}{|l|l|l|l|}
\hline Field & Type & Field size & Keterangan \\
\hline idProgram & Integer & 11 & Id Program \\
\hline kdProgram & Varchar & 3 & Kode program \\
\hline nmProgram & Varchar & 100 & Nama program \\
\hline
\end{tabular}

\subsection{Implementasi}

1. Halaman Login Sistem

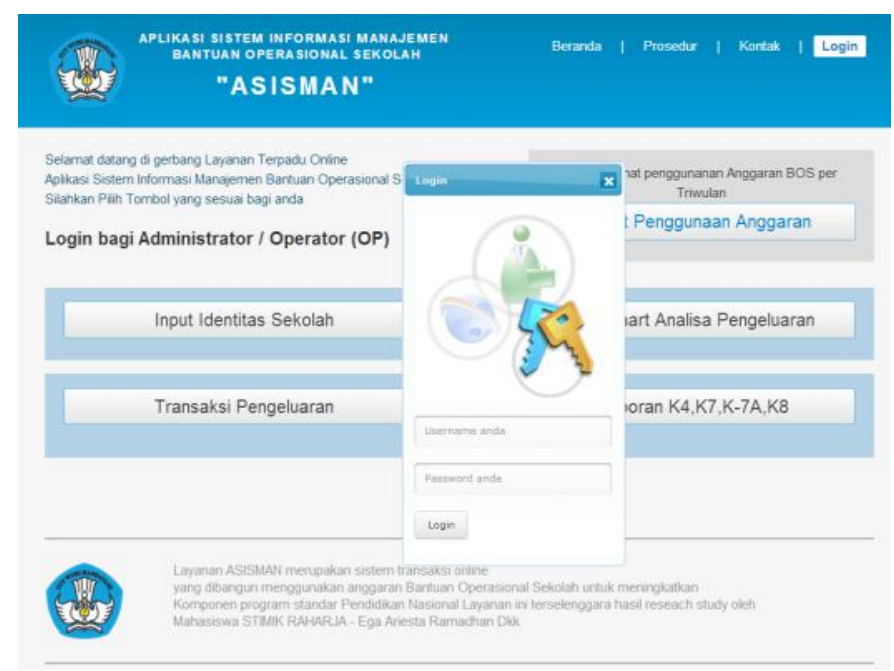

Gambar 1 Halaman menu login 
Halaman login ini berfungsi untuk menjaga keamanan dari orang-orang yang tidak diperkenankan untuk masuk ke halaman sistem informasi penyaluran dana bantuan operasional sekolah di SDN Negeri kota Tangerang.

2. Halaman Utama

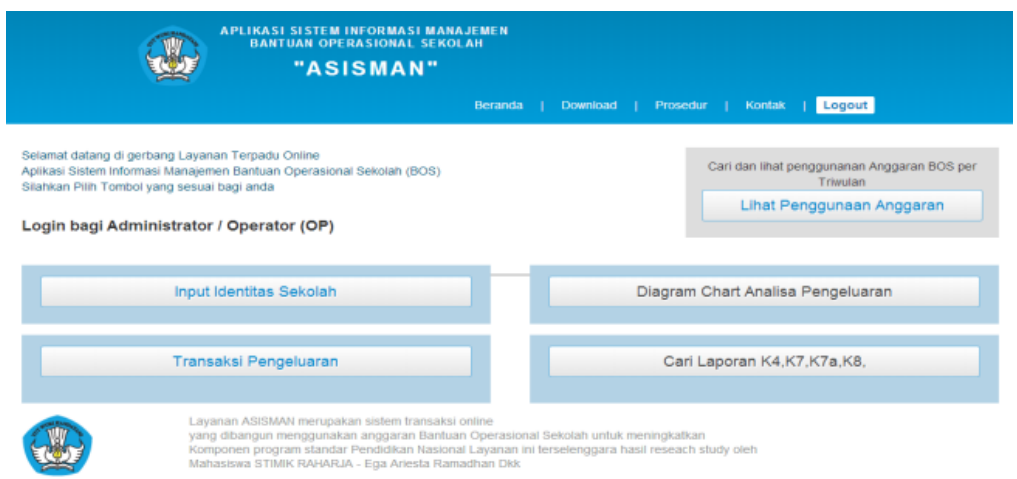

Gambar 3 Halaman menu home

Setelah admin memasukan username dan password yang benar maka akan muncul halaman utama yang bersikian tombol link yang menuju kepada halaman Identitas sekolah, Transaksi, Laporan, Diagram chart analisa informasi pengeluaran jika belum login halaman tersebut tetap tampil namun tidak dapat di akses.

3. Halaman Input Identitas

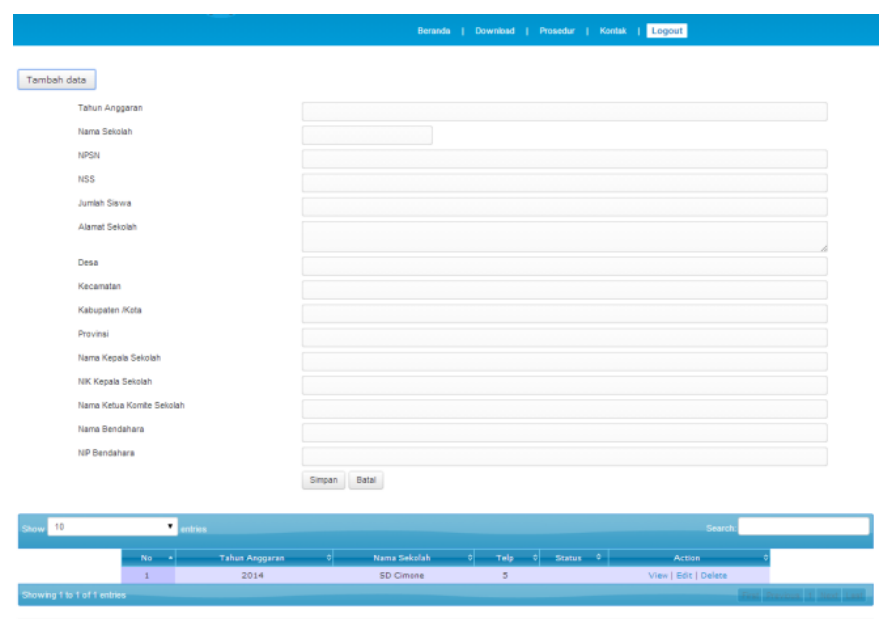

Gambar 4 Halaman menu input identitas sekolah

Dalam halaman menu identitas sekolah maka sistem akan menampilkan isian data sekolah dimana data tersebut akan berguna untuk pada saat membuat laporan. 
4. Halaman Transaksi

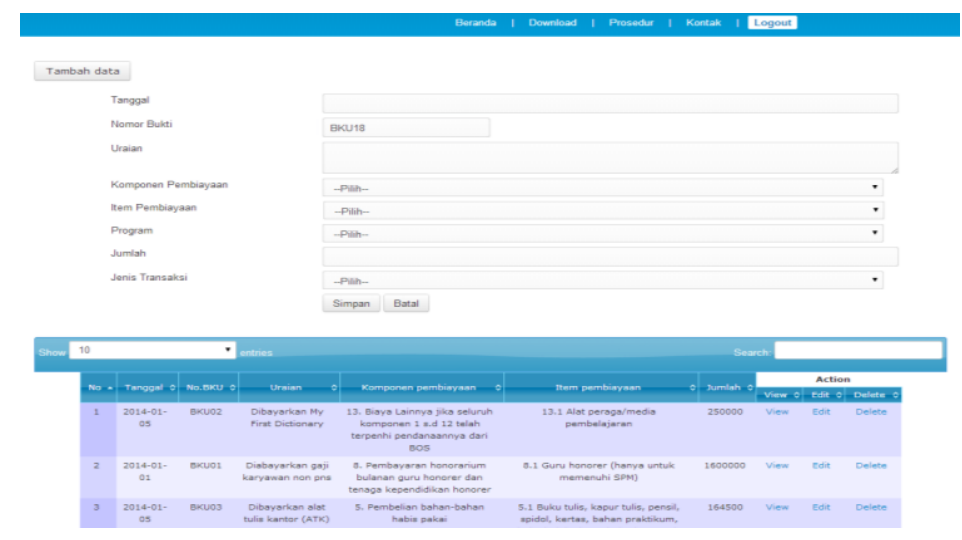

Gambar 5 Halaman menu Transaksi

Pada halaman transaksi dimana proses penginputan berdasarkan kwitansi yang didapat pada saaat melakukan pembelian dan di entri kedalam system sesuai dengan apa yang ditulis dikwitansi pembelian.

5. Halaman Laporan

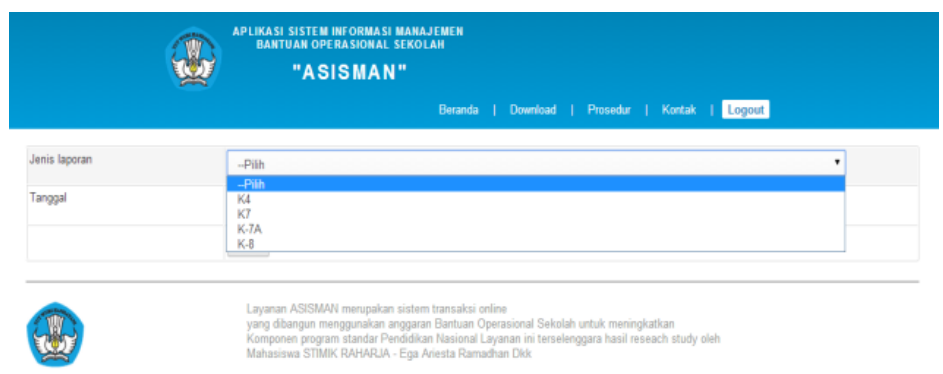

Gambar 6 Halaman menu laporan

Pada halaman menu Laporan ini dimana operator atau tata usaha sekolah dapat mencari format bantuan operasional sekolah yang telah ditetapkan oleh pemerintah pusat dan yang telah diterapkan pada aplikasi ini, sehingga operator atau tata usaha hanya tinggal mencari transaksi berdasarkan waktu yang diinginkan dan jenis format BOS (Bantuan Operasional Sekolah) sesuai apa yang dibutuhkan sehingga dalam pengerjaannya tidak memakan waktu lama seperti yang terjadi pada saat ini.

Laporan format K4

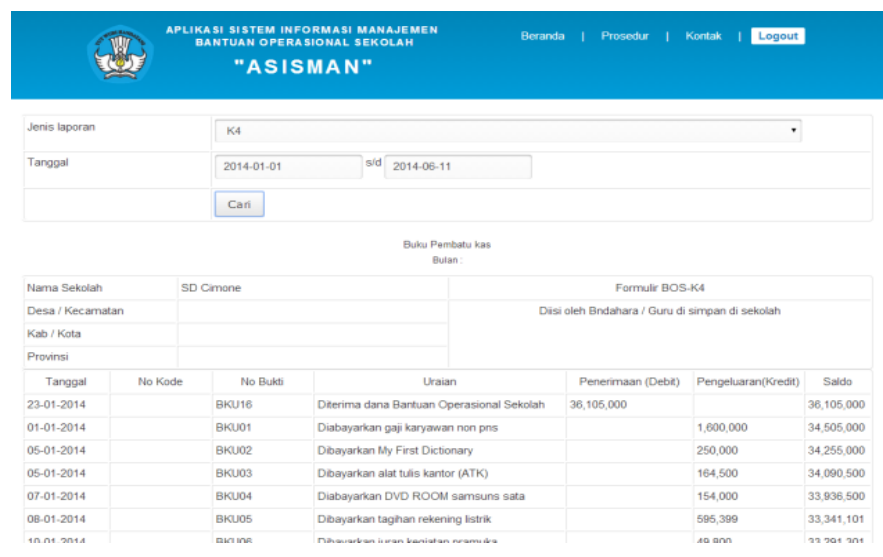

Gambar 7 Halaman menu laporan berbentuk format K4 
Laporan format $\mathrm{K} 7$

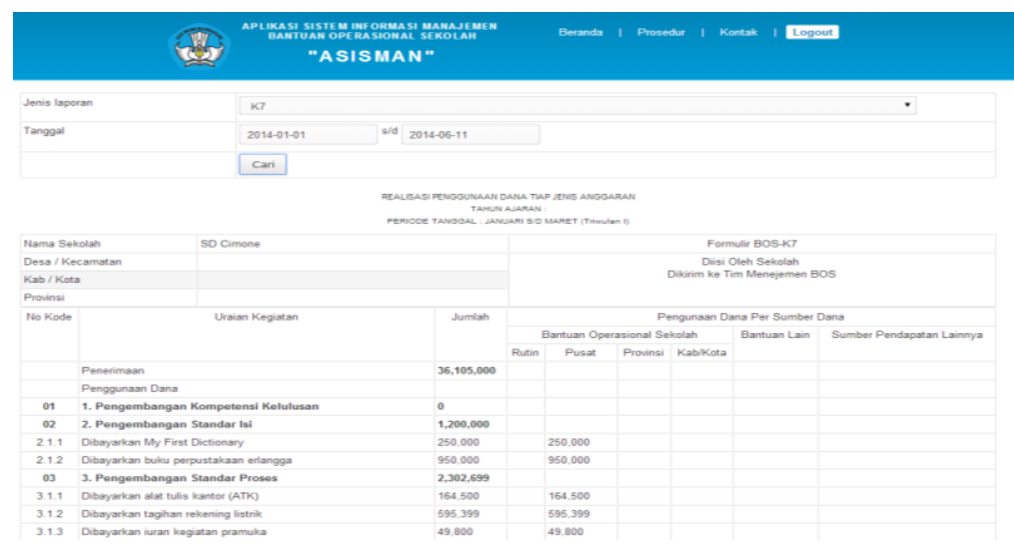

Gambar 8 Halaman menu laporan berbentuk format K7

Pada halaman menu laporan bos juga terdapat format K7 dimana format K7 ini merealisasi penggunaan dana sesuai dengan 8 Standar Pendidikan Nasional.

Laporan format $\mathrm{K} 7 \mathrm{a}$

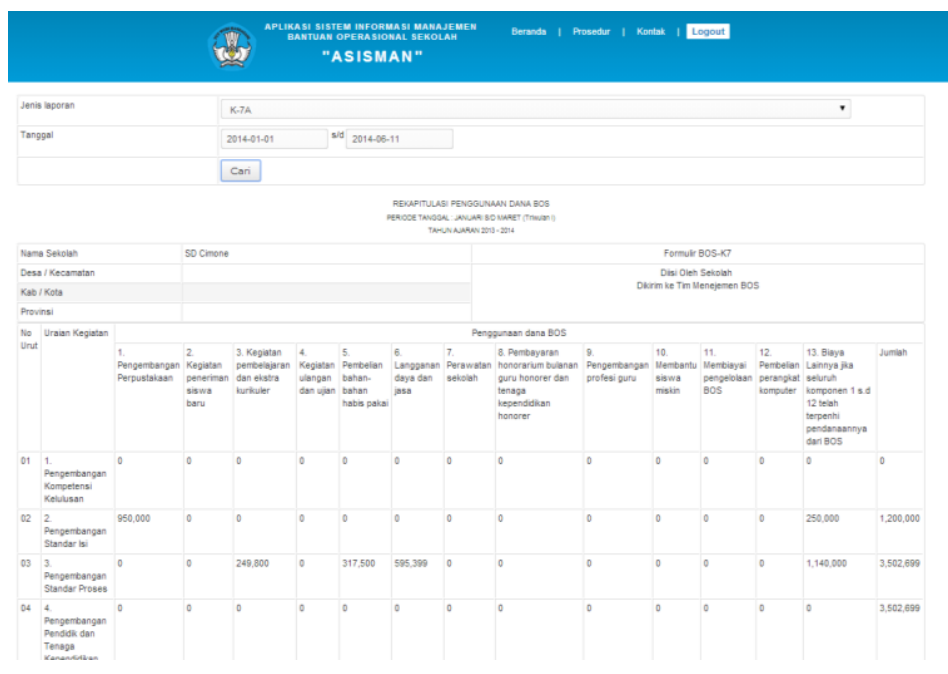

Gambar 9 Halaman menu laporan berbentuk format K7a

Pada halaman menu laporan bos setelah format $\mathrm{K} 7$ ada jgua format $\mathrm{K} 7 \mathrm{a}$ dimana format $\mathrm{K} 7 \mathrm{a}$ ini hasil rekapan dari laporan format K7 dimana terdapat Rekapitulasi Penggunaan Anggaran apa sudah terpenuhi sesuai 8 Standar Pendidikan Nasional dan 13 Komponen BOS yang harus sesuai dengan pentunjuk penggunaan anggaran. 
Format K8

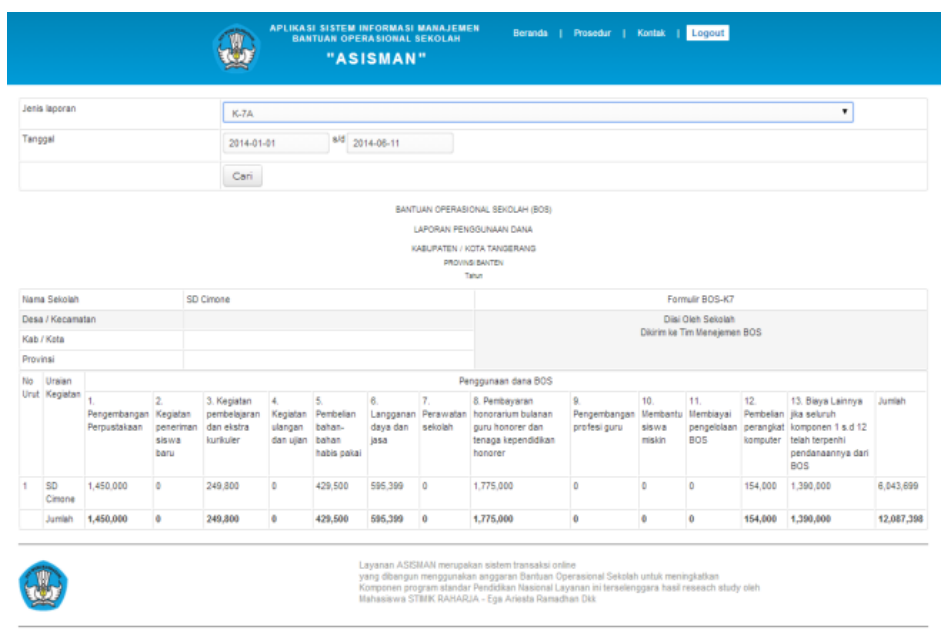

Gambar 10 menu laporan berbentuk format K8a

Didalam format K8 ini ialah dimana penggunaan anggaran dana bantuan operasional sekolah harus sesuai dengan 13 komponen yang harus dipenuhi oleh sekolah, tidak dapat menggunakan anggaran apabila tidak sesuai dengan 13 komponen bos.

\section{KESIMPULAN DAN SARAN}

1. Sistem informasi informasi penyaluran dana bantuan operasional sekolah di SD Negeri Tangerang masih terdapat banyak kendala dalam pembuatan laporan dan informasi terkait penggunaan dana bantuan operasional sekolah tersebut. Terutama pada saat pembuatan laporan, dalam penyusunannya belum adanya mekanisme ataupun sistem yang dibangun untuk memenejemen informasi penyaluran dana bantuan operasional sekolah secara baik, sehingga tidak terstruktur nya dalam pembuatan laporan. Ini mengakibatkan waktu yang lama dan kesabaran dan ketelitian dalam pembuatan laporan ini.

2. Beberapa kendala yang terjadi ialah terlalu banyak menghabiskan kertas untuk mencetak laporan sementara, yaitu laporan yang hanya dilakukan pencatatan berasarkan 13 komponen yang ada didalam buku petunjuk teknis BOS. Sehingga jika terjadi pembelanjaan anggaran belum memenuhi target terhadap 13 komponen yang berada didalam buku petunjuk teknis BOS maka akan dilakukan kembali pencatatan ulang dan mengelompokkan kembali kwitansi-kwitansi pembelian barang dan jasa sesuai dengan 13 komponen pembelanjaan bos.

3. Untuk mengatasi beberapa masalah yang dikemukakan dalam kesimpulan pertama dan kedua maka penulis mengusulkan melakukan pembuatan system informasi penyaluran dana bantuan operasional sekolah, dengan Sistem ini membantu operator sekolah atau tata usaha dan kepala sekolah dalam mencatat semua pembelanjaan yang menggunakan dana bantua operasional sekolah, tidak perlu lagi adanya laporan sementara dan pencatatan ulang dan melalui sistem ini kepala sekolah dapat mengevaluasi pembelanjaan dana bantuan operasional sekolah apa sudah terpenuhi atau belum terpenuhi sesuai dengan ketetapan pemerintah terhadap buku pentujuk teknis bantuan operasional sekolah.

\section{DAFTAR PUSTAKA}

[1] Suprihadi. 2013. Rancang Bangun Sistem Jejaring Klaster Berbasis Web Menggunakan Metode Model View Controller. Vol.6 No.3 - Mei 2013 ISSN: 1978-8282 STMIK Raharja.

[2] Abdul Kadir. 2014. Pengenalan Sistem Informasi. Edisi Revisi. Yogyakarta: Andi Offset. 
[3] Ross.D.Arnold, Jon.P.Wade A Definition of Systems Thinking: A System Approach. Procedia Computer Science. Dikutip: http://www.sciencedirect.com//science/article/pii/S1877050915002860 diakses pada tanggal 8 Maret 2017.

[4] Bambang Hartono. 2013. Sistem Informasi Manajemen Berbasis Komputer. Jakarta: Rineka Cipta.

[5] Taufiq, Rohmat. 2013. Sistem Informasi Manajemen, Konsep Dasar, Analisa Dan Metode Pengembangan. Yogyakarta : Graha Ilmu.

[6] Tohari Hamim. Analisis Serta Perancangan Sistem Informasi Melalui Pendekatan UML. Yogyakarta: Andi Offset. 2014.

[7] Maimunah, Lusyani Sunarya, Nina Larasti.2012. Media Company ProfileSebagai Sarana Penunjang Informasi dan Promosi .Jurnal CCIT Vol.5No.3-Mei 2012.Tangerang:Perguruan Tinggi Raharja.

[8] Pratama, I Putu Agus Eka. 2014. Sistem Informasi dan Implementasinya. Bandung: BI Obses.

[9] Lee, Sunguk .2012 "Unified Modeling Language (UML) For Database System and Computer Applications vol. 5, No.1, March, 2012.

[10] Rio Ridha Ariestyo., Arna Fariza., Ira Prasetya Ningrum ., 2013. Sistem Informasi Pengelolaan Dana Bantua Operasional Sekolah ( Bos ) Di Smp Surabaya. Jurnal Informatika.

[11] Suryati., Bambang Eka Purnama., 2012. Pembangunan Sistem Informasi Pendataan Rakyat Miskin Untuk Program Beras Miskin (Raskin) Pada Desa Mantren Kecamatan Kebonagung Kabupaten Pacitan. Jurnal Speed 13 FTI UNSA Vol 9 No 2 - ISSN: 1979-9330.

[12] Sharipuddin, perancangan sistem informasi Penerima bantuan pada federasi serikat buruh demokrasi seluruh indonesia (fsbdsi) periode berbasis web. Di kutip : http://www.jurnalmsi.stikom-db.ac.id diakses pada tanggal 22 april 2017. 